\title{
A global algorithm for estimating Absolute Salinity
}

\author{
T. J. McDougall ${ }^{1}$, D. R. Jackett ${ }^{2}$, F. J. Millero ${ }^{3}$, R. Pawlowicz ${ }^{4}$, and P. M. Barker ${ }^{1}$ \\ ${ }^{1}$ School of Mathematics and Statistics, University of New South Wales, Sydney, Australia \\ ${ }^{2}$ Deceased, formerly of CSIRO, Hobart, Australia \\ ${ }^{3}$ Rosenstiel School of Marine and Atmospheric Science, University of Miami, Miami, FL33149, USA \\ ${ }^{4}$ Dept. of Earth and Ocean Sciences, University of British Columbia, Vancouver, B.C. V6T 1Z4, Canada \\ Correspondence to: T. J. McDougall (trevor.mcdougall@unsw.edu.au)
}

Received: 17 December 2008 - Published in Ocean Sci. Discuss.: 9 February 2009

Revised: 22 November 2012 - Accepted: 22 November 2012 - Published: 21 December 2012

\begin{abstract}
The International Thermodynamic Equation of Seawater - 2010 has defined the thermodynamic properties of seawater in terms of a new salinity variable, Absolute Salinity, which takes into account the spatial variation of the composition of seawater. Absolute Salinity more accurately reflects the effects of the dissolved material in seawater on the thermodynamic properties (particularly density) than does Practical Salinity.

When a seawater sample has standard composition (i.e. the ratios of the constituents of sea salt are the same as those of surface water of the North Atlantic), Practical Salinity can be used to accurately evaluate the thermodynamic properties of seawater. When seawater is not of standard composition, Practical Salinity alone is not sufficient and the Absolute Salinity Anomaly needs to be estimated; this anomaly is as large as $0.025 \mathrm{~g} \mathrm{~kg}^{-1}$ in the northernmost North Pacific. Here we provide an algorithm for estimating Absolute Salinity Anomaly for any location $(x, y, p)$ in the world ocean.

To develop this algorithm, we used the Absolute Salinity Anomaly that is found by comparing the density calculated from Practical Salinity to the density measured in the laboratory. These estimates of Absolute Salinity Anomaly however are limited to the number of available observations (namely 811). In order to provide a practical method that can be used at any location in the world ocean, we take advantage of approximate relationships between Absolute Salinity Anomaly and silicate concentrations (which are available globally).
\end{abstract}

\section{Introduction}

The composition of the dissolved material in seawater is not exactly constant, but varies a little as a function of depth and from one ocean basin to another. Brewer and Bradshaw (1975) and Millero (2000) pointed out that these spatial variations in the relative composition of seawater impact the relationship between density and Practical Salinity (which is essentially a measure of the conductivity of seawater at a fixed temperature and pressure). The thermodynamic properties of seawater have recently been re-defined by the Intergovernmental Oceanographic Commission (IOC) as TEOS-10 (the International Thermodynamic Equation of Seawater - 2010) in terms of a Gibbs function (or Gibbs potential) which is a function of Absolute Salinity $S_{\mathrm{A}}$ (rather than of Practical Salinity $S_{\mathrm{P}}$ ), temperature and pressure. Absolute Salinity is traditionally defined as the mass fraction of dissolved material in seawater. The use of Absolute Salinity as the salinity argument for the Gibbs function and therefore for all other thermodynamic functions (such as density) is a significant departure from prior practice (EOS-80).

Absolute Salinity $S_{\mathrm{A}}$ is preferred over Practical Salinity $S_{\mathrm{P}}$ because the thermodynamic properties of seawater are directly influenced by the mass of dissolved constituents, whereas Practical Salinity depends only on electrical conductivity. Consider for example exchanging a small amount of pure water with the same mass of silicate in an otherwise isolated seawater sample at constant temperature and pressure. Since silicate is predominantly non-ionic, the conductivity (and therefore Practical Salinity $S_{\mathrm{P}}$ ) is almost unchanged by this exchange but the Absolute Salinity is increased, as is the density. Similarly, if a small mass of say 
$\mathrm{NaCl}$ is added and the same mass of silicate is taken out of a seawater sample, the mass fraction Absolute Salinity will not have changed (and so the density should be almost unchanged) but the Practical Salinity will have increased.

The variations in the relative concentrations of seawater constituents caused by biogeochemical processes actually complicate even the definition of what exactly is meant by "Absolute Salinity". These issues have not been well studied to date, but what is known can be found in Pawlowicz et al. (2011), Wright et al. (2011) and IOC et al. (2010). The Absolute Salinity $S_{\mathrm{A}}$ that is the salinity argument of the TEOS-10 Gibbs function is the version of Absolute Salinity that provides the best estimate of the density of seawater.

As a first step towards incorporating the difference between Practical Salinity $S_{\mathrm{P}}$ and Absolute Salinity $S_{\mathrm{A}}$ in oceanographic practice, Millero et al. (2008a) defined a reference composition of seawater. This reference composition defines exact mole fractions of the major components of seawater (see Table 4 of Millero et al., 2008a). Up to the accuracy of measurements to date, this reference composition is identical to that of standard seawater (which is surface water from a specific region of the North Atlantic). Using the most recent atomic weights, Millero et al. (2008a) calculated the mass-fraction Absolute Salinity of seawater of reference composition, and this salinity they called ReferenceComposition Salinity, $S_{\mathrm{R}}$. For the range of salinities where Practical Salinities are defined (that is, in the range $2<S_{\mathrm{P}}<$ 42), it was shown that

$S_{\mathrm{R}} \approx u_{\mathrm{PS}} S_{\mathrm{P}}$ where $u_{\mathrm{PS}} \equiv(35.16504 / 35) \mathrm{g} \mathrm{kg}^{-1}$

For practical purposes, this relationship can be taken to be an equality since the approximate nature of this relation only reflects the accuracy of the algorithms used in the definition of Practical Salinity. This follows from the fact that the Practical Salinity is intended to be precisely conservative during mixing and also during changes in temperature and pressure that occur without exchange of mass with the surroundings.

The Reference-Composition Salinity scale of TEOS-10 is defined such that a seawater sample whose Practical Salinity $S_{\mathrm{P}}$ is 35 has a Reference-Composition Salinity $S_{\mathrm{R}}$ of precisely $35.16504 \mathrm{~g} \mathrm{~kg}^{-1}$. Millero et al. (2008a) estimate that the absolute uncertainty associated with using this value as an estimate of the Absolute Salinity of Reference-Composition Seawater is $\pm 0.007 \mathrm{~g} \mathrm{~kg}^{-1}$; thus, the numerical difference between the Reference Salinity expressed in $\mathrm{g} \mathrm{kg}^{-1}$ and Practical Salinity is about 24 times larger than this estimate of uncertainty. The difference, 0.16504 , is also large compared to our ability to measure Practical Salinity at sea (which can be as precise as \pm 0.002 ). Understanding how this discrepancy was introduced requires consideration of some historical details that influenced the definition of Practical Salinity. The details are presented in Millero et al. (2008a) and in Millero (2010) and are briefly summarised here. There are two primary reasons for this discrepancy. First, and most significant, in the original evaporation technique used to estimate salinity, some volatile components of the dissolved material were lost so the amount of dissolved material was underestimated. Second, the approximate relation determined by Knudsen (1901) to determine $S(\% \circ)$ from measurements of Chlorinity $\mathrm{Cl}(\% \circ)$ was based on the analysis of only nine samples (one from the Red Sea, one from the North Atlantic, one from the North Sea and six from the Baltic Sea), so biasing the result towards the Baltic which we now know to not be representative of the open ocean.

Millero et al. (2008a) list six reasons for introducing Reference Salinity, the last of which was the ability to use Reference Salinity as a stepping stone to Absolute Salinity, thereby being able to calculate density more accurately. Heuristically this can be thought of as reflecting the fact that some nonionic species (such as silicate) affect the density of a seawater sample without significantly affecting its conductivity or its Practical Salinity. But silica is not the only quantity whose concentration changes in the global ocean, and Pawlowicz (2010a) and Pawlowicz et al. (2011) have constructed chemical models of conductivity and of density to estimate how the concentrations of several species affect both the electrical conductivity (and therefore Practical Salinity) and the density (and therefore the Absolute Salinity) of seawater. The chemistry involved in those papers will be unfamiliar to many physical oceanographers, but can be summarised as follows (see Wright et al. (2011) and IOC et al. (2010)). If measurements are available of the total alkalinity, dissolved inorganic carbon, and the nitrate and silicate concentrations, the Absolute Salinity $S_{\mathrm{A}}$ of seawater may be estimated from

$$
\begin{aligned}
\left(S_{\mathrm{A}}-S_{\mathrm{R}}\right) /\left(\mathrm{g} \mathrm{kg}^{-1}\right)= & \left(55.6 \Delta \mathrm{TA}+4.7 \Delta \mathrm{DIC}+38.9 \mathrm{NO}_{3}^{-}+50.7 \mathrm{Si}(\mathrm{OH})_{4}\right) / \\
& \left(\mathrm{mol} \mathrm{kg}^{-1}\right),
\end{aligned}
$$

where $\mathrm{NO}_{3}^{-}$and $\mathrm{Si}(\mathrm{OH})_{4}$ are the nitrate and silicate concentrations of the seawater sample (measured in mol kg-1), while $\triangle \mathrm{TA}$ and $\triangle \mathrm{DIC}$ are the differences between the total alkalinity (TA) and dissolved inorganic carbon (DIC) of the sample and the corresponding values of our best estimates of TA and DIC in standard seawater, measured in mol kg-1. For standard seawater our best estimates of TA and DIC are $0.0023\left(S_{\mathrm{P}} / 35\right) \mathrm{mol} \mathrm{kg}^{-1}$ and $0.00208\left(S_{\mathrm{P}} / 35\right) \mathrm{mol} \mathrm{kg}^{-1}$, respectively (from Pawlowicz, 2010a; Pawlowicz et al., 2011 and Wright et al., 2011). The coefficients in Eq. (2) are reasonably similar to the corresponding expression of Brewer and Bradshaw (1975) (as corrected by Millero et al., 1976a): when expressed as the salinity anomaly $S_{\mathrm{A}}-S_{\mathrm{R}}$ rather than as the corresponding density anomaly $\rho-\rho_{\mathrm{R}}$, their expression corresponding to Eq. (2) had the coefficients 71.4, -12.8 , 31.9 and 59.9 compared with the coefficients 55.6, 4.7, 38.9 and 50.7, respectively, in Eq. (2).

When sufficient nutrient and carbon-chemistry data are available, the Absolute Salinity Anomaly $\delta S_{\mathrm{A}} \equiv S_{\mathrm{A}}-S_{\mathrm{R}}$ is best estimated from Eq. (2) above. If an accurate direct measurement of density is available, then Absolute Salinity can 
Table 1. List of nomenclature.

\begin{tabular}{|c|c|}
\hline$\lambda$ & Latitude, degrees north, $-90^{\circ} \mathrm{N}$ to $+90^{\circ} \mathrm{N}$. \\
\hline$\phi$ & $\begin{array}{l}\text { Longitude, degrees east from the Greenwich meridian, } \\
0^{\circ} \mathrm{E}-360^{\circ} \mathrm{E} \text {. }\end{array}$ \\
\hline$g$ & $\begin{array}{l}\text { Specific Gibbs energy (Gibbs function), } g\left(S_{\mathrm{A}}, t, p\right) \text {, } \\
\mathrm{J} \mathrm{kg}^{-1} \text {. }\end{array}$ \\
\hline$S_{\mathrm{P}}$ & $\begin{array}{l}\text { Practical Salinity (salinity calculated through conduc- } \\
\text { tivity ratio and expressed on the Practical Salinity scale } \\
\text { of } 1978 \text {; UNESCO, 1981, 1983) }\end{array}$ \\
\hline$S_{\mathrm{A}}$ & $\begin{array}{l}\text { Absolute Salinity, defined in TEOS-10 to approximate } \\
\text { the mass fraction of dissolved material in seawater, } \\
\mathrm{g} \mathrm{kg}^{-1} \text {. }\end{array}$ \\
\hline$S_{\mathrm{R}}$ & $\begin{array}{l}\text { Reference-Composition Salinity, } \quad \mathrm{g} \mathrm{kg}^{-1}, \quad S_{\mathrm{R}}= \\
u_{\mathrm{PS}} S_{\mathrm{P}}=\left(S_{\mathrm{SO}} / 35\right) S_{\mathrm{P}} \text {. } \quad \text { "Reference-Composition } \\
\text { Salinity" is often shortened to "Reference Salinity". }\end{array}$ \\
\hline$S_{\mathrm{SO}}$ & $\begin{array}{l}\text { Standard ocean Absolute Salinity, } 35.16504 \mathrm{gkg}^{-1} \text {, be- } \\
\text { ing exactly } 35 u_{\mathrm{PS}} \text {, corresponding to the standard ocean } \\
\text { Practical Salinity of } 35 \text {. (see Millero et al., 2008a and } \\
\text { Feistel, 2008). }\end{array}$ \\
\hline$p$ & Sea pressure, dbar. \\
\hline$P$ & $\begin{array}{l}\text { Absolute pressure, Pa. } P /(\mathrm{Pa})=10^{4}(\mathrm{p} / \mathrm{dbar})+ \\
P_{0} /(\mathrm{Pa}) \text { where } P_{0} \text { is the standard ocean surface } \\
\text { pressure, } 101325 \mathrm{~Pa} \text {. }\end{array}$ \\
\hline$t$ & Celsius temperature, ITS- $90,{ }^{\circ} \mathrm{C}$ \\
\hline$u_{\mathrm{PS}}$ & $\begin{array}{l}\text { Conversion factor of Practical Salinity to Reference } \\
\text { Salinity, exactly defined as } u_{\mathrm{PS}} \equiv(35.16504 / 35) \mathrm{gkg}^{-1} \\
\text { (see Millero et al., 2008a and Feistel, 2008). }\end{array}$ \\
\hline$\delta S_{\mathrm{A}}$ & $\begin{array}{l}\text { The Absolute Salinity Anomaly, } \delta S_{\mathrm{A}}=S_{\mathrm{A}}-S_{\mathrm{R}} \text {, is the } \\
\text { difference between Absolute Salinity and Reference- } \\
\text { Composition Salinity, } \mathrm{g} \mathrm{kg}^{-1} \text {. }\end{array}$ \\
\hline$R^{\delta}$ & $\begin{array}{l}\text { Absolute Salinity Anomaly Ratio, } R^{\delta} \equiv \delta S_{\mathrm{A}}^{\text {atlas }} / S_{\mathrm{R}}^{\text {atlas }} \text {, } \\
\text { the ratio of the stored atlas values of Absolute Salinity } \\
\text { Anomaly, } \delta S_{\mathrm{A}}^{\text {atlas }} \text {, and Reference Salinity } S_{\mathrm{R}}^{\text {atlas }} \text {. }\end{array}$ \\
\hline$\rho$ & Density, $\mathrm{kg} \mathrm{m}^{-3}, \rho^{-1}=g_{p}=\partial g /\left.\partial p\right|_{S_{\mathrm{A}}, T}$ \\
\hline
\end{tabular}

be evaluated using the TEOS-10 expression for density as a function of Absolute Salinity. The present paper is concerned with the common situation where nutrient and carbonchemistry data are not available, and there are also no direct measurements of density. The method we develop is based on some rather sparse direct measurements of density on seawater samples taken from the global ocean, interpolated to the spatial position of the seawater sample using an atlas of silicate data as an intermediary. The aim is to be able to estimate Absolute Salinity Anomaly $\delta S_{\mathrm{A}}$ from simply knowledge of the seawater sample's location in space, i.e. as $\delta S_{\mathrm{A}}=\delta S_{\mathrm{A}}(x, y, p)$. In this way Absolute Salinity can be estimated as

$S_{\mathrm{A}}=\left(35.16504 \mathrm{~g} \mathrm{~kg}^{-1} / 35\right) S_{\mathrm{P}}+\delta S_{\mathrm{A}}(x, y, p)$.

\section{Using density measurements to estimate $\delta S_{\mathrm{A}}$}

The fundamental measurements required to provide a method for estimating Absolute Salinity in terms of values of Practical Salinity have been reported in Millero et al. (1976a,
1978, 2000, 2008b, 2009). To this data we add, in Table 2 , measurements of density on samples taken from the Southern Ocean. These papers (including Table 2 of the present paper) describe measurements of 811 seawater samples from around the globe at the locations shown in Fig. 1. The Practical Salinity $S_{\mathrm{P}}$ and the density $\rho^{\text {lab }}$ of each seawater sample are measured in the laboratory at $25^{\circ} \mathrm{C}$ and at atmospheric pressure (assumed to be $p=0 \mathrm{dbar}$, or an absolute pressure $P$ of exactly $101325 \mathrm{~Pa}$ ) using a vibrating tube densimeter (Kremling, 1971). The Absolute Salinity of the seawater sample is estimated from the laboratory density measurement and the TEOS-10 equation of state (Feistel, 2008), IAPWS (2008), Feistel et al. (2008), IOC et al. (2010)), essentially by solving the equation $\rho^{\text {lab }}=\rho\left(S_{\mathrm{A}}, 25^{\circ} \mathrm{C}, 0 \mathrm{dbar}\right)$ for $S_{\mathrm{A}}$. In detail, the laboratory data were used to determine the density difference $\delta \rho=\rho^{\text {lab }}-\rho\left(S_{\mathrm{R}}, 25^{\circ} \mathrm{C}, 0 \mathrm{dbar}\right)$ and this density difference was used with the partial derivative of density with respect to Absolute Salinity at $25^{\circ} \mathrm{C}$ and $0 \mathrm{dbar}$, namely $\partial \rho /\left.\partial S_{\mathrm{A}}\right|_{t=25^{\circ} \mathrm{C}, p=0 \mathrm{dbar}} \approx 0.7519 \mathrm{~kg} \mathrm{~m}^{-3} /\left(\mathrm{g} \mathrm{kg}^{-1}\right)$, to estimate $\delta S_{\mathrm{A}}=S_{\mathrm{A}}-S_{\mathrm{R}}$ as $\delta \rho /\left[0.7519 \mathrm{~kg} \mathrm{~m}^{-3} /\left(\mathrm{g} \mathrm{kg}^{-1}\right)\right]$. This is the method for estimating $\delta S_{\mathrm{A}}$ suggested by Millero et al. (2008a) (their Eq. (7.2)).

The salinity difference $\delta S_{\mathrm{A}}$ obtained in this way is plotted in Fig. 2a against the silicate concentrations of the seawater samples using all the data published in Millero et al. (1976a, $1978,2000,2008 b, 2009$ ) as well as the Southern Ocean data of this paper. These previous papers have considered various measured properties of seawater to correlate with $\delta S_{\mathrm{A}}$ (such as silicate, total alkalinity, total carbon dioxide and nitrate) and found that silicate correlates the best. This is fortunate as there are more measurements of silicate in the ocean databases than either total alkalinity or total carbon dioxide. The reason for the good performance of silicate alone is thought to be that (a) it is itself substantially correlated with the other variables responsible for errors in using Practical Salinity to determine Absolute Salinity, (b) it accounts for a substantial fraction (of around 0.6) of the typical variations in concentrations $\left(\mathrm{g} \mathrm{kg}^{-1}\right)$ of the above species and (c) being essentially non-ionic, its presence has little effect on conductivity while having a direct effect on density (Millero et al., 1976b, 2000).

The data in Fig. 2a, representing seawater samples from throughout the world oceans can be fitted by the simple proportional relationship with silicate (as indicated by the straight line in the figure)

$\delta S_{\mathrm{A}} /\left(\mathrm{g} \mathrm{kg}^{-1}\right)=\left(S_{\mathrm{A}}-S_{\mathrm{R}}\right) /\left(\mathrm{g} \mathrm{kg}^{-1}\right)=98.24\left(\mathrm{Si}(\mathrm{OH})_{4} /\left(\mathrm{mol} \mathrm{kg}^{-1}\right)\right)$ Global

The standard error in this fit on Fig. 2a is $0.0054 \mathrm{~g} \mathrm{~kg}^{-1}$.

\section{The regressions of $\delta S_{\mathrm{A}}$ with silicate in different ocean basins}

When the data in Fig. 2a are coloured by ocean basin it becomes clear that the data from different ocean basins lie 


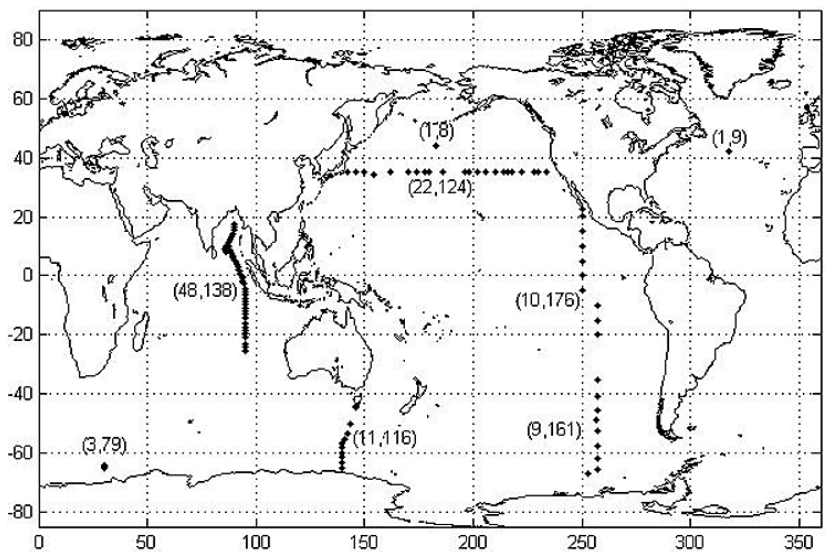

Fig. 1. Map showing the locations where the 811 seawater samples were collected whose density measurements form the basis of this paper. The first number in the brackets indicates the number of casts from which the samples were collected in each region and the second number is the number of seawater samples.

either predominantly above or below the straight line fit of Eq. (4) as a function of silicate concentration. For example, the data from the North Pacific and North Indian basins clearly were on average above the straight line of Fig. 2a while the data from the Southern Ocean were clustered below the line. This is not unexpected since the spatially variable relative concentrations of different constituents of seawater will not exactly co-vary with silicate.

In order to incorporate this spatially distinct information we decided to perform different fits for the different ocean basins. Because of the dominant role of the Antarctic Circumpolar Current in transporting seawater zonally in the high southern latitudes, we posit that the zonal variation in the relative constituents of seawater may be weak and so we grouped all the data south of $30^{\circ} \mathrm{S}$ together and these data were fitted in a separate linear fit with silicate, as shown in Fig. 3. This fit (for latitudes south of $30^{\circ} \mathrm{S}$, that is for $\left.\lambda \leq-30^{\circ}\right)$ is

$$
\delta S_{\mathrm{A}} /\left(\mathrm{g} \mathrm{kg}^{-1}\right)=74.884\left(\mathrm{Si}(\mathrm{OH})_{4} /\left(\mathrm{mol} \mathrm{kg}^{-1}\right)\right) \text { Southern Ocean }
$$

The dots on Fig. $3 \mathrm{a}$ are the individual data points and the open circles are the values of the straight line fit Eq. (5) to the data, evaluated at the same silicate values as the data points. The error in the fit between the laboratory-determined values of $\delta S_{\mathrm{A}}=S_{\mathrm{A}}-S_{\mathrm{R}}$ and the value from the linear fit Eq. (5) is shown in Fig. 3b. The associated standard error is $0.0026 \mathrm{~g} \mathrm{~kg}^{-1}$.

The data north of $30^{\circ} \mathrm{S}$ in each of the Pacific, Indian and Atlantic Oceans was treated separately. In each of these three regions we constrained the fit to match Eq. (5) at $30^{\circ} \mathrm{S}$ and allowed the slope of the fit to vary linearly with latitude.
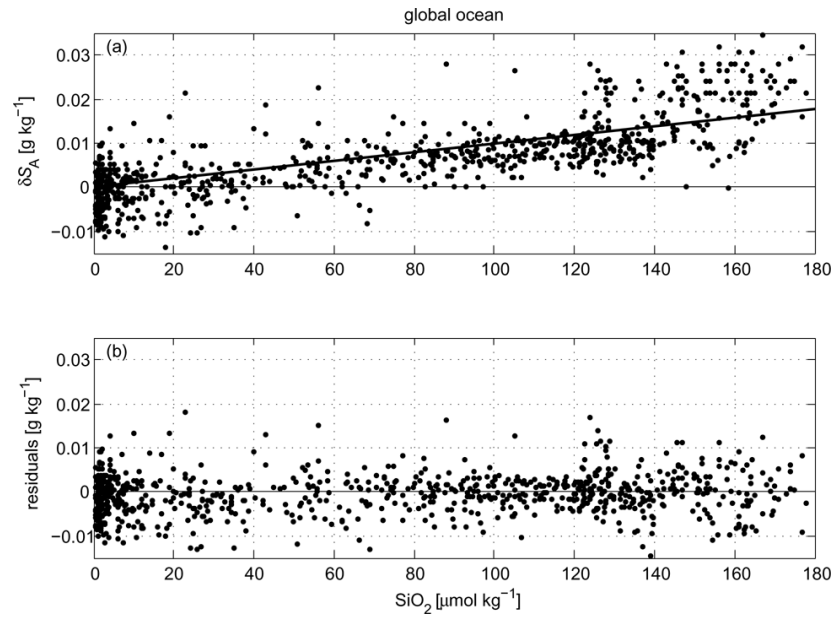

Fig. 2. (a) The laboratory-determined values of $\delta S_{\mathrm{A}}=S_{\mathrm{A}}-S_{\mathrm{R}}$ for all 811 samples from the world ocean plotted against the silicate value of each sample. The straight-line fit to the data is given in Eq. (2) and fits these data with a standard error of $0.0054 \mathrm{~g} \mathrm{~kg}^{-1}$. This straight-line fit is not the model that is adopted in this paper. The mean square of these values of $\delta S_{\mathrm{A}}$ is the square of $0.0107 \mathrm{~g} \mathrm{~kg}^{-1}$. (b) The difference between the laboratorydetermined value of $\delta S_{\mathrm{A}}$ and the model for $\delta S_{\mathrm{A}}$ developed in this paper represented by Eqs. (3)-(6). The standard error of these residuals is $0.0048 \mathrm{~g} \mathrm{~kg}^{-1}$.

The resulting fits were (for latitudes north of $30^{\circ} \mathrm{S}$, that is for $\left.\lambda \geq-30^{\circ}\right)$

$\delta S_{\mathrm{A}} /\left(\mathrm{g} \mathrm{kg}^{-1}\right)=74.884\left(1+0.3622\left[\lambda / 30^{\circ}+1\right]\right)\left(\mathrm{Si}(\mathrm{OH})_{4} /\left(\mathrm{mol} \mathrm{kg}^{-1}\right)\right)$
$\delta$ Pacific
$\delta S_{\mathrm{A}} /\left(\mathrm{g} \mathrm{kg}^{-1}\right)=74.884\left(1+0.3861\left[\lambda / 30^{\circ}+1\right]\right)\left(\mathrm{Si}(\mathrm{OH})_{4} /\left(\mathrm{mol} \mathrm{kg}^{-1}\right)\right)$ Indian
$\delta S_{\mathrm{A}} /\left(\mathrm{g} \mathrm{kg}^{-1}\right)=74.884\left(1+1.0028\left[\lambda / 30^{\circ}+1\right]\right)\left(\mathrm{Si}(\mathrm{OH})_{4} /\left(\mathrm{mol} \mathrm{kg}^{-1}\right)\right)$ Atlantic $(8)$

These fits in the Pacific, Indian, and Atlantic Oceans north of $30^{\circ} \mathrm{S}$ are shown in Figs. 4-6. These fits are intended to be used from $30^{\circ} \mathrm{S}$ through the equator and up to the northernmost extent of these ocean basins. In the absence of density data from the Arctic Ocean, our present recommendation is that the Arctic Ocean be characterised by the same equation as the Atlantic, namely equation Eq. (8).

The fitted circles in panels (a) of Figs. 4, 5 and 6 do not fall on a straight line on these plots because the fit depends on both latitude and silicate. The reason why part of a straight line is visible for the Pacific data is because much of the Pacific data is from a single latitude (see Fig. 1). It is not known why the standard deviation of the data for the Pacific and Indian Oceans are significantly larger than for the Southern Ocean. It may be that the laboratory technique for determining the conductivity and density of the samples has improved, since the Southern Ocean data was the most recent data to be measured; but this is only a conjecture at this stage. As is well-known, the silicate concentrations in the North Atlantic are quite low and it is comforting to see in Fig. 6 that 

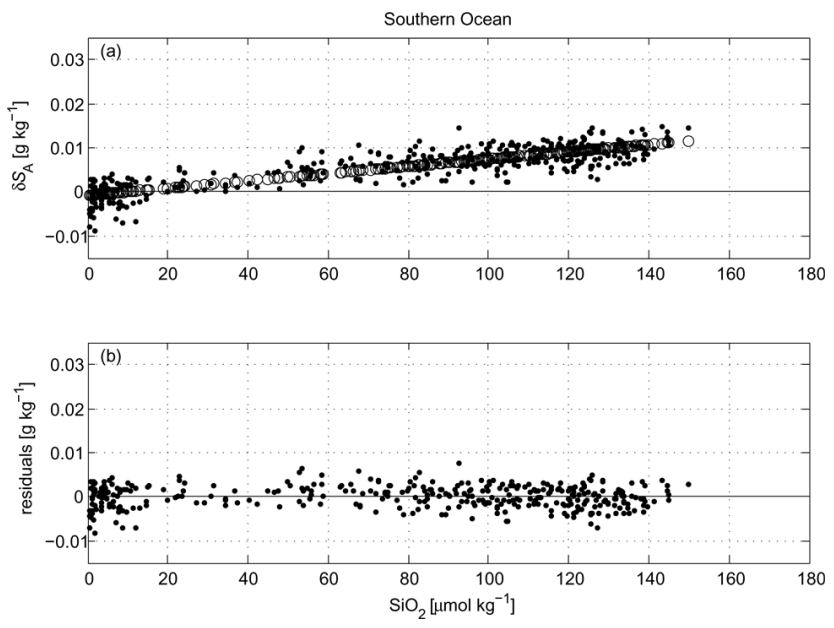

Fig. 3. (a) Laboratory-determined values of $\delta S_{\mathrm{A}}=S_{\mathrm{A}}-S_{\mathrm{R}}$ from all longitudes and for latitudes south of $30^{\circ} \mathrm{S}$ plotted against the silicate value of each seawater sample. The data are the small dots and the open circles are the values obtained from the fit (3) to this data. (b) The residuals between the laboratory-determined values of $\delta S_{\mathrm{A}}$ and the values found from the fit (3).

the laboratory-determined values of $\delta S_{\mathrm{A}}=S_{\mathrm{A}}-S_{\mathrm{R}}$ are also rather small there.

For each of the Southern, Pacific and Indian Ocean data sets, we also performed fits that allowed an offset of $\delta S_{\mathrm{A}}$ at zero silicate. In no case did this significantly improve the fits. We have also plotted the residuals as functions of pressure and of latitude and detect no obvious trend in either plot.

We now have a "model" for estimating the Absolute Salinity for data from the major ocean basins. One needs to know the Practical Salinity, the location of the sample (its pressure, its latitude and which ocean basin it is from) and the silicate concentration of the sample. Having these pieces of information, one can use the appropriate equation from Eq. (5) to Eq. (8) to calculate $\delta S_{\mathrm{A}}=S_{\mathrm{A}}-S_{\mathrm{R}}$ for the seawater sample. We have done this for the 811 samples for which we also have the laboratory-determined values of $\delta S_{\mathrm{A}}=S_{\mathrm{A}}-S_{\mathrm{R}}$. The error between the laboratory-determined values of $\delta S_{\mathrm{A}}=$ $S_{\mathrm{A}}-S_{\mathrm{R}}$ and the "model"-based values is shown as the scatter plot of errors in Fig. 2b. The standard error of these data is $0.0048 \mathrm{~g} \mathrm{~kg}^{-1}$ which is a little less than that from the straightline fit of Eq. (4) and Fig. 2a, namely $0.0054 \mathrm{~g} \mathrm{~kg}^{-1}$. This improvement amounts to a reduction in error variance of $21 \%$ $\left.(0.0048 / 0.0054)^{2}=0.79\right)$ and has been obtained by having different fits in the different ocean basins.

\section{Interpolation of the silicate atlas}

We now use these correlations between $\delta S_{\mathrm{A}}=S_{\mathrm{A}}-S_{\mathrm{R}}$ and the silicate concentration to develop a practical algorithm that can be used by oceanographers to estimate Absolute Salinity, given the Practical Salinity and the location of a
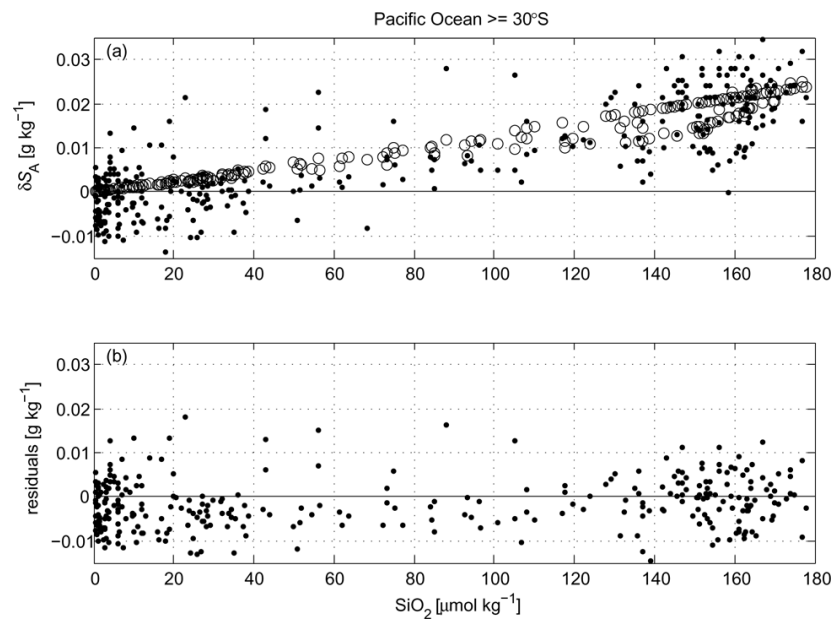

Fig. 4. (a) Laboratory-determined values of $\delta S_{\mathrm{A}}=S_{\mathrm{A}}-S_{\mathrm{R}}$ for seawater samples from both the North and South Pacific Ocean basins north of $30^{\circ} \mathrm{S}$. The data are plotted against the silicate value of each seawater sample. The data are the small dots and the open circles are the values obtained from the fit (4) to this data. (b) The residuals between the laboratory-determined values of $\delta S_{\mathrm{A}}$ and the values found from the fit (4).

seawater sample. We do this by utilizing the global atlas of Gouretski and Koltermann (2004) for (among other properties) silicate. We first use the above four Eqs. (5)-(8) to replace all the silicate data in the world ocean with values of Absolute Salinity Anomaly $\delta S_{\mathrm{A}}=S_{\mathrm{A}}-S_{\mathrm{R}}$. We now describe in detail how the global atlas of $\delta S_{\mathrm{A}}$ was formed.

The Gouretski and Koltermann (2004) atlas has its silicate field $\left(\mathrm{SiO}_{2}\right)$ at a $1 / 2$ degree by $1 / 2$ degree horizontal resolution at 45 pressure levels ranging from the sea surface to 6131 dbar. Unfortunately this silicate field does not cover the entire global ocean, but only $99.75 \%$ of the ocean for which other hydrographic data is defined. These missing values are filled in by averaging over the silicate values found at the four locations in the east/north/west/south directions at a distance of $1 / 2$ degree in latitude or longitude from the point in question. In the first instance this was done along isopycnals using precise calculations of the four neutral tangent planes in all four directions. This was performed iteratively until no further missing values needed filling, when only $0.05 \%$ of the data remained without silicate values. Apart from the Caspian Sea where silicate values are not available from the Gouretski and Koltermann atlas (the Caspian Sea is excluded from the present data set; see Millero et al. (2008c) for an equation of state for these waters), the locations of the remaining missing values are all coastal and so were filled in by averaging along geopotentials. This still left $0.03 \%$ of the ocean without a silicate value. All of these were against continental boundaries and were very shallow, so these missing values were set to zero, consistent with the surrounding nearzero silicate data at these shallow depths. 
Table 2. Practical Salinity $S_{\mathrm{P}}$ and silicate $\mathrm{SiO}_{2}$ measured in the Southern Ocean on the CASO SR3 AA0806 voyage south of Tasmania at the longitudes, latitudes and pressures shown. The densities of seawater samples collected at these locations were measured in the laboratory at $t=25^{\circ} \mathrm{C}$ and $p=0 \mathrm{dbar}$. The values of $\delta \rho$ in the table are differences between the measured densities in the laboratory and those evaluated via the TEOS-10 equation of state using the Practical Salinity at $t=25^{\circ} \mathrm{C}$ and $p=0$ dbar. The Absolute Salinity Anomaly $\delta S_{\mathrm{A}}$ is calculated from $\delta \rho$ as simply $\delta \rho /\left[0.7519 \mathrm{~kg} \mathrm{~m}^{-3} /\left(\mathrm{g} \mathrm{kg}^{-1}\right)\right]$.

\begin{tabular}{|c|c|c|c|c|c|c|}
\hline$\varphi\left({ }^{\circ} \mathrm{E}\right)$ & $\lambda\left({ }^{\circ} \mathrm{S}\right)$ & $p$ (dbar) & $S_{\mathrm{P}}$ & $\begin{array}{r}\mathrm{SiO}_{2} \\
\left(\mu \mathrm{mol} \mathrm{kg}{ }^{-1}\right)\end{array}$ & $\begin{array}{r}\delta \rho \\
\left(\mathrm{kg} \mathrm{m}^{-3}\right)\end{array}$ & $\begin{array}{r}\delta S_{\mathrm{A}} \\
\left(\mathrm{g} \mathrm{kg}^{-1}\right)\end{array}$ \\
\hline $139^{\circ} 55^{\prime}$ & $65^{\circ} 24^{\prime}$ & 2375 & 34.689 & 102.09 & 0.0029 & 0.0038 \\
\hline $139^{\circ} 55^{\prime}$ & $65^{\circ} 24^{\prime}$ & 2353 & 34.661 & 102.09 & 0.0040 & 0.0053 \\
\hline $139^{\circ} 55^{\prime}$ & $65^{\circ} 24^{\prime}$ & 2201 & 34.664 & 102.09 & 0.0037 & 0.0049 \\
\hline $139^{\circ} 55^{\prime}$ & $65^{\circ} 24^{\prime}$ & 2001 & 34.682 & 104.57 & 0.0072 & 0.0095 \\
\hline $139^{\circ} 55^{\prime}$ & $65^{\circ} 24^{\prime}$ & 1800 & 34.692 & 107.07 & 0.0056 & 0.0075 \\
\hline $139^{\circ} 55^{\prime}$ & $65^{\circ} 24^{\prime}$ & 1401 & 34.699 & 111.24 & 0.0052 & 0.0070 \\
\hline $139^{\circ} 55^{\prime}$ & $65^{\circ} 24^{\prime}$ & 999 & 34.691 & 109.98 & 0.0083 & 0.0110 \\
\hline $139^{\circ} 55^{\prime}$ & $65^{\circ} 24^{\prime}$ & 600 & 34.634 & 99.50 & 0.0073 & 0.0097 \\
\hline $139^{\circ} 55^{\prime}$ & $65^{\circ} 24^{\prime}$ & 301 & 34.509 & 84.02 & 0.0038 & 0.0051 \\
\hline $139^{\circ} 55^{\prime}$ & $65^{\circ} 24^{\prime}$ & 90 & 34.142 & 58.59 & 0.0031 & 0.0042 \\
\hline $139^{\circ} 55^{\prime}$ & $65^{\circ} 24^{\prime}$ & 10 & 34.128 & 47.76 & 0.0006 & 0.0008 \\
\hline $139^{\circ} 50^{\prime}$ & $63^{\circ} 21^{\prime}$ & 3830 & 34.696 & 103.21 & 0.0045 & 0.0060 \\
\hline $139^{\circ} 50^{\prime}$ & $63^{\circ} 21^{\prime}$ & 3783 & 34.711 & 104.03 & 0.0032 & 0.0042 \\
\hline $139^{\circ} 50^{\prime}$ & $63^{\circ} 21^{\prime}$ & 3401 & 34.749 & 119.70 & 0.0035 & 0.0046 \\
\hline $139^{\circ} 50^{\prime}$ & $63^{\circ} 21^{\prime}$ & 3101 & 34.739 & 121.34 & 0.0041 & 0.0054 \\
\hline $139^{\circ} 50^{\prime}$ & $63^{\circ} 21^{\prime}$ & 2801 & 34.700 & 121.33 & 0.0035 & 0.0046 \\
\hline $139^{\circ} 50^{\prime}$ & $63^{\circ} 21^{\prime}$ & 2202 & 34.735 & 125.42 & 0.0040 & 0.0053 \\
\hline $139^{\circ} 50^{\prime}$ & $63^{\circ} 21^{\prime}$ & 1300 & 34.762 & 104.77 & 0.0017 & 0.0022 \\
\hline $139^{\circ} 50^{\prime}$ & $63^{\circ} 21^{\prime}$ & 598 & 34.775 & 88.25 & 0.0018 & 0.0025 \\
\hline $139^{\circ} 50^{\prime}$ & $63^{\circ} 21^{\prime}$ & 200 & 34.630 & 81.88 & 0.0044 & 0.0058 \\
\hline $139^{\circ} 50^{\prime}$ & $63^{\circ} 21^{\prime}$ & 49 & 34.029 & 30.62 & 0.0015 & 0.0019 \\
\hline $139^{\circ} 50^{\prime}$ & $63^{\circ} 21^{\prime}$ & 5 & 33.909 & 23.61 & 0.0010 & 0.0014 \\
\hline $139^{\circ} 50^{\prime}$ & $61^{\circ} 21^{\prime}$ & 4388 & 34.834 & 115.54 & 0.0033 & 0.0044 \\
\hline $139^{\circ} 50^{\prime}$ & $61^{\circ} 21^{\prime}$ & 4203 & 34.767 & 122.59 & 0.0049 & 0.0065 \\
\hline $139^{\circ} 50^{\prime}$ & $61^{\circ} 21^{\prime}$ & 3801 & 34.694 & 131.71 & 0.0081 & 0.0107 \\
\hline $139^{\circ} 50^{\prime}$ & $61^{\circ} 21^{\prime}$ & 3401 & 34.707 & 131.71 & 0.0073 & 0.0097 \\
\hline $139^{\circ} 50^{\prime}$ & $61^{\circ} 21^{\prime}$ & 3001 & 34.745 & 128.82 & 0.0065 & 0.0087 \\
\hline $139^{\circ} 50^{\prime}$ & $61^{\circ} 21^{\prime}$ & 2200 & 34.730 & 115.59 & 0.0078 & 0.0104 \\
\hline $139^{\circ} 50^{\prime}$ & $61^{\circ} 21^{\prime}$ & 1501 & 34.749 & 98.61 & 0.0065 & 0.0086 \\
\hline $139^{\circ} 50^{\prime}$ & $61^{\circ} 21^{\prime}$ & 700 & 34.705 & 82.75 & 0.0037 & 0.0050 \\
\hline $139^{\circ} 50^{\prime}$ & $61^{\circ} 21^{\prime}$ & 301 & 34.532 & 73.53 & 0.0036 & 0.0047 \\
\hline $139^{\circ} 50^{\prime}$ & $61^{\circ} 21^{\prime}$ & 69 & 33.944 & 22.80 & 0.0037 & 0.0049 \\
\hline $139^{\circ} 50^{\prime}$ & $61^{\circ} 21^{\prime}$ & 5 & 33.801 & 11.94 & 0.0016 & 0.0022 \\
\hline $139^{\circ} 52^{\prime}$ & $59^{\circ} 51^{\prime}$ & 4529 & 34.685 & 134.63 & 0.0059 & 0.0078 \\
\hline $139^{\circ} 52^{\prime}$ & $59^{\circ} 51^{\prime}$ & 4199 & 34.733 & 132.62 & 0.0085 & 0.0114 \\
\hline $139^{\circ} 52^{\prime}$ & $59^{\circ} 51^{\prime}$ & 3799 & 34.697 & 133.48 & 0.0078 & 0.0104 \\
\hline $139^{\circ} 52^{\prime}$ & $59^{\circ} 51^{\prime}$ & 3399 & 34.731 & 129.73 & 0.0040 & 0.0054 \\
\hline $139^{\circ} 52^{\prime}$ & $59^{\circ} 51^{\prime}$ & 2600 & 34.841 & 118.88 & 0.0039 & 0.0052 \\
\hline $139^{\circ} 52^{\prime}$ & $59^{\circ} 51^{\prime}$ & 2198 & 34.742 & 110.53 & 0.0058 & 0.0077 \\
\hline $139^{\circ} 52^{\prime}$ & $59^{\circ} 51^{\prime}$ & 1201 & 34.812 & 85.47 & 0.0058 & 0.0078 \\
\hline $139^{\circ} 52^{\prime}$ & $59^{\circ} 51^{\prime}$ & 500 & 34.637 & 74.99 & 0.0042 & 0.0055 \\
\hline $139^{\circ} 52^{\prime}$ & $59^{\circ} 51^{\prime}$ & 198 & 34.296 & 53.76 & 0.0037 & 0.0049 \\
\hline $139^{\circ} 52^{\prime}$ & $59^{\circ} 51^{\prime}$ & 51 & 33.839 & 5.97 & 0.0030 & 0.0039 \\
\hline $139^{\circ} 52^{\prime}$ & $59^{\circ} 51^{\prime}$ & 5 & 33.798 & 5.93 & 0.0019 & 0.0025 \\
\hline
\end{tabular}


Table 2. Continued.

\begin{tabular}{|c|c|c|c|c|c|c|}
\hline$\varphi\left({ }^{\circ} \mathrm{E}\right)$ & $\lambda\left({ }^{\circ} \mathrm{S}\right)$ & $p$ (dbar) & $S_{\mathrm{P}}$ & $\begin{array}{r}\mathrm{SiO}_{2} \\
\left(\mu \mathrm{mol} \mathrm{kg}{ }^{-1}\right)\end{array}$ & $\begin{array}{r}\delta \rho \\
\left(\mathrm{kg} \mathrm{m}^{-3}\right)\end{array}$ & $\begin{array}{r}\delta S_{\mathrm{A}} \\
\left(\mathrm{g} \mathrm{kg}^{-1}\right)\end{array}$ \\
\hline $139^{\circ} 51^{\prime}$ & $58^{\circ} 21^{\prime}$ & 4032 & 34.749 & 138.84 & 0.0054 & 0.0072 \\
\hline $139^{\circ} 51^{\prime}$ & $58^{\circ} 21^{\prime}$ & 3602 & 34.703 & 133.09 & 0.0082 & 0.0109 \\
\hline $139^{\circ} 51^{\prime}$ & $58^{\circ} 21^{\prime}$ & 3199 & 34.729 & 125.70 & 0.0026 & 0.0034 \\
\hline $139^{\circ} 51^{\prime}$ & $58^{\circ} 21^{\prime}$ & 2900 & 34.744 & 121.18 & 0.0083 & 0.0111 \\
\hline $139^{\circ} 51^{\prime}$ & $58^{\circ} 21^{\prime}$ & 2602 & 34.752 & 112.65 & 0.0063 & 0.0083 \\
\hline $139^{\circ} 51^{\prime}$ & $58^{\circ} 21^{\prime}$ & 2300 & 34.906 & 105.98 & 0.0079 & 0.0105 \\
\hline $139^{\circ} 51^{\prime}$ & $58^{\circ} 21^{\prime}$ & 1701 & 34.817 & 90.37 & 0.0052 & 0.0069 \\
\hline $139^{\circ} 51^{\prime}$ & $58^{\circ} 21^{\prime}$ & 898 & 34.684 & 77.23 & 0.0037 & 0.0049 \\
\hline $139^{\circ} 51^{\prime}$ & $58^{\circ} 21^{\prime}$ & 401 & 34.363 & 55.74 & 0.0032 & 0.0042 \\
\hline $139^{\circ} 51^{\prime}$ & $58^{\circ} 21^{\prime}$ & 149 & 34.020 & 24.28 & 0.0033 & 0.0043 \\
\hline $139^{\circ} 51^{\prime}$ & $58^{\circ} 21^{\prime}$ & 30 & 33.820 & 1.87 & 0.0003 & 0.0004 \\
\hline $139^{\circ} 51^{\prime}$ & $56^{\circ} 56^{\prime}$ & 4179 & 34.782 & 138.70 & 0.0076 & 0.0101 \\
\hline $139^{\circ} 51^{\prime}$ & $56^{\circ} 56^{\prime}$ & 4134 & 34.708 & 138.69 & 0.0065 & 0.0086 \\
\hline $139^{\circ} 51^{\prime}$ & $56^{\circ} 56^{\prime}$ & 3801 & 34.717 & 133.85 & 0.0067 & 0.0089 \\
\hline $139^{\circ} 51^{\prime}$ & $56^{\circ} 56^{\prime}$ & 2999 & 34.728 & 118.52 & 0.0054 & 0.0072 \\
\hline $139^{\circ} 51^{\prime}$ & $56^{\circ} 56^{\prime}$ & 2500 & 34.811 & 106.42 & 0.0047 & 0.0062 \\
\hline $139^{\circ} 51^{\prime}$ & $56^{\circ} 56^{\prime}$ & 1400 & 34.747 & 80.60 & 0.0070 & 0.0094 \\
\hline $139^{\circ} 51^{\prime}$ & $56^{\circ} 56^{\prime}$ & 902 & 34.774 & 72.41 & 0.0066 & 0.0088 \\
\hline $139^{\circ} 51^{\prime}$ & $56^{\circ} 56^{\prime}$ & 121 & 33.864 & 11.08 & 0.0021 & 0.0028 \\
\hline $140^{\circ} 44^{\prime}$ & $55^{\circ} 30^{\prime}$ & 4222 & 34.705 & 138.14 & 0.0077 & 0.0102 \\
\hline $140^{\circ} 44^{\prime}$ & $55^{\circ} 30^{\prime}$ & 3904 & 34.732 & 134.89 & 0.0064 & 0.0085 \\
\hline $140^{\circ} 44^{\prime}$ & $55^{\circ} 30^{\prime}$ & 3599 & 34.901 & 132.87 & 0.0057 & 0.0075 \\
\hline $140^{\circ} 44^{\prime}$ & $55^{\circ} 30^{\prime}$ & 3295 & 34.831 & 120.71 & 0.0056 & 0.0074 \\
\hline $140^{\circ} 44^{\prime}$ & $55^{\circ} 30^{\prime}$ & 2703 & 34.765 & 119.90 & 0.0054 & 0.0071 \\
\hline $140^{\circ} 44^{\prime}$ & $55^{\circ} 30^{\prime}$ & 2102 & 34.789 & 106.12 & 0.0053 & 0.0071 \\
\hline $140^{\circ} 44^{\prime}$ & $55^{\circ} 30^{\prime}$ & 1501 & 34.776 & 89.92 & 0.0031 & 0.0041 \\
\hline $140^{\circ} 44^{\prime}$ & $55^{\circ} 30^{\prime}$ & 897 & 34.826 & 79.95 & 0.0053 & 0.0070 \\
\hline $140^{\circ} 44^{\prime}$ & $55^{\circ} 30^{\prime}$ & 597 & 34.639 & 74.32 & 0.0046 & 0.0061 \\
\hline $140^{\circ} 44^{\prime}$ & $55^{\circ} 30^{\prime}$ & 301 & 34.468 & 58.08 & 0.0018 & 0.0024 \\
\hline $140^{\circ} 44^{\prime}$ & $55^{\circ} 30^{\prime}$ & 71 & 33.751 & 3.06 & 0.0004 & 0.0006 \\
\hline $141^{\circ} 52^{\prime}$ & $53^{\circ} 35^{\prime}$ & 2658 & 34.749 & 111.31 & 0.0075 & 0.0100 \\
\hline $141^{\circ} 52^{\prime}$ & $53^{\circ} 35^{\prime}$ & 2606 & 34.747 & 110.48 & 0.0070 & 0.0093 \\
\hline $141^{\circ} 52^{\prime}$ & $53^{\circ} 35^{\prime}$ & 2401 & 34.759 & 103.49 & 0.0079 & 0.0105 \\
\hline $141^{\circ} 52^{\prime}$ & $53^{\circ} 35^{\prime}$ & 2199 & 34.766 & 99.38 & 0.0046 & 0.0061 \\
\hline $141^{\circ} 52^{\prime}$ & $53^{\circ} 35^{\prime}$ & 2000 & 34.765 & 94.45 & 0.0044 & 0.0059 \\
\hline $141^{\circ} 52^{\prime}$ & $53^{\circ} 35^{\prime}$ & 1700 & 34.756 & 87.87 & 0.0062 & 0.0082 \\
\hline $141^{\circ} 52^{\prime}$ & $53^{\circ} 35^{\prime}$ & 999 & 34.641 & 75.41 & 0.0061 & 0.0080 \\
\hline $141^{\circ} 52^{\prime}$ & $53^{\circ} 35^{\prime}$ & 702 & 34.502 & 66.82 & 0.0022 & 0.0029 \\
\hline $141^{\circ} 52^{\prime}$ & $53^{\circ} 35^{\prime}$ & 401 & 34.272 & 42.35 & 0.0008 & 0.0011 \\
\hline $141^{\circ} 52^{\prime}$ & $53^{\circ} 35^{\prime}$ & 149 & 33.963 & 15.34 & 0.0023 & 0.0031 \\
\hline $141^{\circ} 52^{\prime}$ & $53^{\circ} 35^{\prime}$ & 31 & 33.764 & 1.58 & 0.0016 & 0.0021 \\
\hline
\end{tabular}

We then sub-sampled this $1 / 2$ degree resolution ocean at 4 degrees in both latitude and longitude in the domain $\left[0^{\circ} \mathrm{E}\right.$, $\left.356^{\circ} \mathrm{E}\right] \times\left[-78^{\circ} \mathrm{N}, 90^{\circ} \mathrm{N}\right]$. The latitude numbers have been chosen to exactly capture the northern boundary, making the computational scheme in the latitudinal direction straightforward. Since the southern-most data is located at $78.5^{\circ} \mathrm{S}$, the lower boundary at $78^{\circ} \mathrm{S}$ captures silicate values down to $82^{\circ} \mathrm{S}$. The east/west boundary condition at the Greenwich meridian is accommodated by replicating the data along the $0^{\circ} \mathrm{E}$ meridian at $360^{\circ} \mathrm{E}$. 
Table 2. Continued.

\begin{tabular}{|c|c|c|c|c|c|c|}
\hline$\varphi\left({ }^{\circ} \mathrm{E}\right)$ & $\lambda\left({ }^{\circ} \mathrm{S}\right)$ & $p$ (dbar) & $S_{\mathrm{P}}$ & $\begin{array}{r}\mathrm{SiO}_{2} \\
\left(\mu \mathrm{mol} \mathrm{kg}{ }^{-1}\right)\end{array}$ & $\begin{array}{r}\delta \rho \\
\left(\mathrm{kg} \mathrm{m}^{-3}\right)\end{array}$ & $\begin{array}{r}\delta S_{\mathrm{A}} \\
\left(\mathrm{g} \mathrm{kg}^{-1}\right)\end{array}$ \\
\hline $143^{\circ} 40^{\prime}$ & $50^{\circ} 10^{\prime}$ & 3297 & 34.748 & 112.10 & 0.0072 & 0.0096 \\
\hline $143^{\circ} 40^{\prime}$ & $50^{\circ} 10^{\prime}$ & 3049 & 34.749 & 100.70 & 0.0055 & 0.0074 \\
\hline $143^{\circ} 40^{\prime}$ & $50^{\circ} 10^{\prime}$ & 2599 & 34.767 & 89.30 & 0.0019 & 0.0025 \\
\hline $143^{\circ} 40^{\prime}$ & $50^{\circ} 10^{\prime}$ & 2300 & 34.740 & 83.60 & 0.0062 & 0.0083 \\
\hline $143^{\circ} 40^{\prime}$ & $50^{\circ} 10^{\prime}$ & 1603 & 34.520 & 66.43 & 0.0045 & 0.0060 \\
\hline $143^{\circ} 40^{\prime}$ & $50^{\circ} 10^{\prime}$ & 1052 & 34.330 & 27.31 & 0.0000 & 0.0000 \\
\hline $143^{\circ} 40^{\prime}$ & $50^{\circ} 10^{\prime}$ & 698 & 34.511 & 9.08 & 0.0013 & 0.0017 \\
\hline $143^{\circ} 40^{\prime}$ & $50^{\circ} 10^{\prime}$ & 401 & 34.618 & 4.26 & 0.0015 & 0.0020 \\
\hline $143^{\circ} 40^{\prime}$ & $50^{\circ} 10^{\prime}$ & 53 & 34.598 & 1.37 & 0.0006 & 0.0008 \\
\hline $146^{\circ} 03^{\prime}$ & $44^{\circ} 43^{\prime}$ & 3267 & 34.858 & 114.05 & 0.0001 & 0.0002 \\
\hline $146^{\circ} 03^{\prime}$ & $44^{\circ} 43^{\prime}$ & 3216 & 34.854 & 112.41 & 0.0061 & 0.0082 \\
\hline $146^{\circ} 03^{\prime}$ & $44^{\circ} 43^{\prime}$ & 2900 & 34.831 & 105.87 & 0.0085 & 0.0113 \\
\hline $146^{\circ} 03^{\prime}$ & $44^{\circ} 43^{\prime}$ & 2600 & 34.778 & 99.74 & 0.0066 & 0.0087 \\
\hline $146^{\circ} 03^{\prime}$ & $44^{\circ} 43^{\prime}$ & 2301 & 34.766 & 94.83 & 0.0077 & 0.0102 \\
\hline $146^{\circ} 03^{\prime}$ & $44^{\circ} 43^{\prime}$ & 2101 & 34.768 & 88.29 & 0.0061 & 0.0082 \\
\hline $146^{\circ} 03^{\prime}$ & $44^{\circ} 43^{\prime}$ & 1501 & 34.673 & 74.30 & 0.0049 & 0.0065 \\
\hline $146^{\circ} 03^{\prime}$ & $44^{\circ} 43^{\prime}$ & 699 & 34.589 & 10.05 & 0.0024 & 0.0032 \\
\hline $146^{\circ} 03^{\prime}$ & $44^{\circ} 43^{\prime}$ & 301 & 34.919 & 3.38 & 0.0001 & 0.0001 \\
\hline $146^{\circ} 03^{\prime}$ & $44^{\circ} 43^{\prime}$ & 79 & 35.275 & 0.95 & 0.0010 & 0.0013 \\
\hline $146^{\circ} 03^{\prime}$ & $44^{\circ} 43^{\prime}$ & 12 & 35.173 & 1.42 & 0.0021 & 0.0027 \\
\hline $146^{\circ} 12^{\prime}$ & $44^{\circ} 23^{\prime}$ & 2346 & 34.756 & 98.23 & 0.0082 & 0.0109 \\
\hline $146^{\circ} 12^{\prime}$ & $44^{\circ} 23^{\prime}$ & 2307 & 34.763 & 96.51 & 0.0040 & 0.0053 \\
\hline $146^{\circ} 12^{\prime}$ & $44^{\circ} 23^{\prime}$ & 2097 & 34.707 & 90.04 & 0.0053 & 0.0070 \\
\hline $146^{\circ} 12^{\prime}$ & $44^{\circ} 23^{\prime}$ & 1901 & 34.679 & 85.95 & 0.0074 & 0.0098 \\
\hline $146^{\circ} 12^{\prime}$ & $44^{\circ} 23^{\prime}$ & 1697 & 34.612 & 78.58 & 0.0051 & 0.0067 \\
\hline $146^{\circ} 12^{\prime}$ & $44^{\circ} 23^{\prime}$ & 1500 & 34.550 & 74.85 & 0.0049 & 0.0065 \\
\hline $146^{\circ} 12^{\prime}$ & $44^{\circ} 23^{\prime}$ & 1003 & 34.454 & 31.47 & 0.0033 & 0.0044 \\
\hline $146^{\circ} 12^{\prime}$ & $44^{\circ} 23^{\prime}$ & 701 & 34.572 & 8.18 & 0.0012 & 0.0016 \\
\hline $146^{\circ} 12^{\prime}$ & $44^{\circ} 23^{\prime}$ & 399 & 34.672 & 4.22 & 0.0006 & 0.0008 \\
\hline $146^{\circ} 12^{\prime}$ & $44^{\circ} 23^{\prime}$ & 120 & 35.016 & 1.77 & 0.0007 & 0.0009 \\
\hline $146^{\circ} 12^{\prime}$ & $44^{\circ} 23^{\prime}$ & 6 & 34.981 & 0.71 & 0.0021 & 0.0028 \\
\hline
\end{tabular}

\section{Taking account of dilution/concentration by precipitation and evaporation}

An algorithm to calculate the Absolute Salinity $S_{\mathrm{A}}$ of a seawater sample, given its location and its Practical Salinity $S_{\mathrm{P}}$, could simply be the sum of sample's Reference Salinity $S_{\mathrm{R}}=u_{\mathrm{PS}} S_{\mathrm{P}}$ and the spatially-interpolated Absolute Salinity Anomaly calculated as described above in this paper. However we have adopted a slight modification to this procedure to better account for the dilution/concentration of surface seawater by precipitation/evaporation, and the dilution of open ocean water with river water. In this procedure the values of both the Reference Salinity from the global Gouretski and Koltermann (2004) hydrographic atlas $S_{\mathrm{R}}^{\text {atlas }}$ and the Absolute Salinity Anomaly $\delta S_{\mathrm{A}}^{\text {atlas }}$ calculated from the silicate values in this same atlas using Eqs. (5)-(8) above are used to form the ratio $R^{\delta} \equiv \delta S_{\mathrm{A}}^{\text {atlas }} / S_{\mathrm{R}}^{\text {atlas }}$ of these atlas values of Absolute Salinity Anomaly and Reference Salinity. In the TEOS-10 software it is values of the Absolute Salinity Anomaly Ratio, $R^{\delta}$, that are stored as a function of latitude, longitude and pressure on a regular $4^{\circ} \times 4^{\circ}$ grid in latitude and longitude. It is these values of $R^{\delta}$ that are interpolated onto the latitude, longitude and pressure of an oceanographic observation, and the Absolute Salinity Anomaly $\delta S_{\mathrm{A}}$ of an oceanographic observation is calculated from

$\delta S_{\mathrm{A}}=R^{\delta} S_{\mathrm{R}}$ where $R^{\delta} \equiv \delta S_{\mathrm{A}}^{\text {atlas }} / S_{\mathrm{R}}^{\text {atlas }}$ Non-Baltic

and $S_{\mathrm{R}}$ is the Reference Salinity of the oceanographic observation. For the bulk of the ocean this expression for $\delta S_{\mathrm{A}}$ is almost the same as simply setting $\delta S_{\mathrm{A}}$ equal to $\delta S_{\mathrm{A}}^{\text {atlas }}$, but the use of Eq. (9) is preferable in situations where the sample's Reference Salinity is small, such as in rivers, in estuaries and after a rain shower at the sea surface in the open ocean. In these situations the influence of the ocean's biogeochemical processes on $\delta S_{\mathrm{A}}$ should approach zero as $S_{\mathrm{R}}$ approaches zero, and this is achieved by Eq. (9). Substituting 

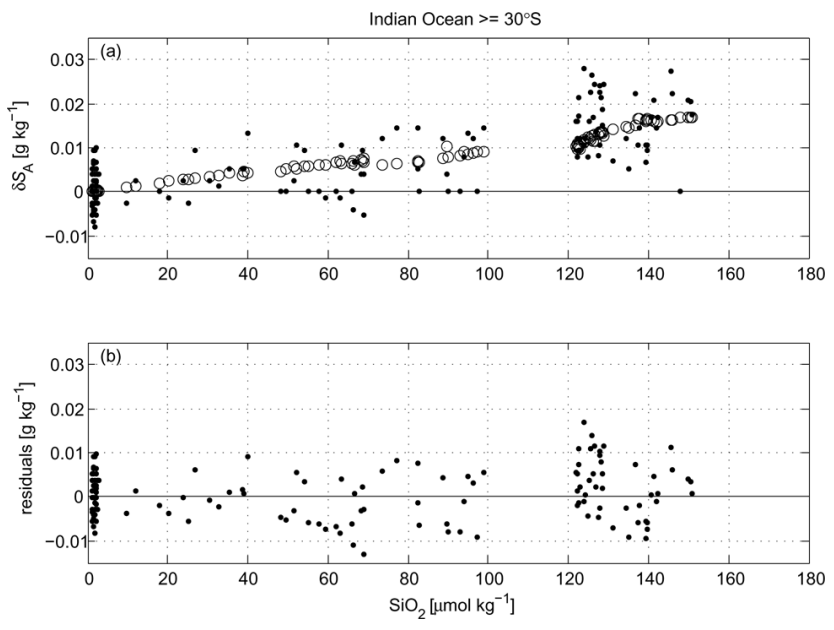

Fig. 5. (a) Laboratory-determined values of $\delta S_{\mathrm{A}}=S_{\mathrm{A}}-S_{\mathrm{R}}$ for seawater samples from both the North and South Indian Ocean north of $30^{\circ} \mathrm{S}$. The data are plotted against the silicate value of each seawater sample. The data are the small dots and the circles are the values obtained from the fit (5) to this data. (b) The residuals between the laboratory-determined values of $\delta S_{\mathrm{A}}$ and the values found from the fit (5).

Eq. (9) into the relation $S_{\mathrm{A}}=S_{\mathrm{R}}+\delta S_{\mathrm{A}}$, we see that Absolute Salinity $S_{\mathrm{A}}$ is evaluated as

$S_{\mathrm{A}}=u_{\mathrm{PS}} S_{\mathrm{P}}\left(1+R^{\delta}\right)=\frac{35.16504 \mathrm{~g} \mathrm{~kg}^{-1}}{35} S_{\mathrm{P}}\left(1+R^{\delta}\right) \quad$ Non-Baltic

In more detail, the interpolation of $R^{\delta}$ in the TEOS-10 computer software to the physical location of a seawater sample proceeds as follows. The numerical "cube" in the atlas that contains the location in question can be identified with the simplest of arithmetic operations in $x-y$ space since the longitude and latitude grids are regular. When values on the upper or lower faces of the cube are missing, these values are replaced with the mean of the valid $R^{\delta}(\mathrm{x}, \mathrm{y}, \mathrm{p})$ values on these same faces. When the seawater sample is deeper than the deepest non-zero $R^{\delta}(\mathrm{x}, \mathrm{y}, \mathrm{p})$ data in the global atlas at this $(x, y)$ location, the pressure of the seawater sample is artificially deemed to be the maximum pressure of non-zero $R^{\delta}$ (x, $y, p)$ values directly above the sample and the interpolation then proceeds as normal.

In Fig. 7a we have plotted a map of the silicate data (in $\mu \mathrm{mol} \mathrm{kg}{ }^{-1}$ ) from the Gouretski and Koltermann (2004) atlas at a pressure of $2000 \mathrm{dbar}$ (20 Mpa), while in Fig. $7 \mathrm{~b}$ is shown the Absolute Salinity Anomaly $\delta S_{\mathrm{A}}$ (actually of $\delta S_{\mathrm{A}}^{\text {atlas }}$ ) at the same pressure. The maximum difference between the North Atlantic and North Pacific oceans at 2000 dbar is in excess of $0.025 \mathrm{~g} \mathrm{~kg}^{-1}$.

\section{Special treatment of ocean boundaries}

The North Atlantic and North Pacific Oceans are closer than four degrees of latitude or longitude apart in the vicinity of
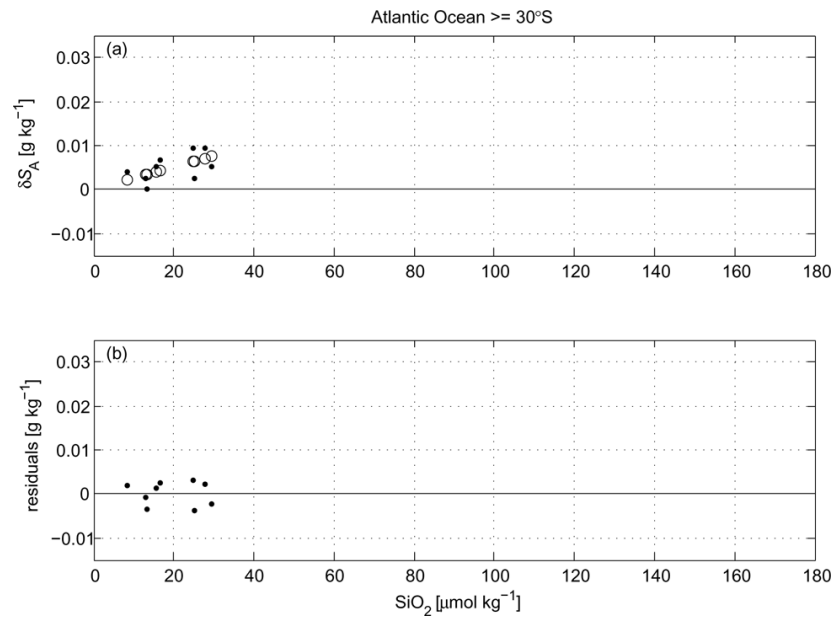

Fig. 6. (a) Laboratory-determined values of $\delta S_{\mathrm{A}}=S_{\mathrm{A}}-S_{\mathrm{R}}$ for seawater samples from the North Atlantic Ocean. The data are plotted against the silicate value of each seawater sample. The data are the small dots and the open circles are the values obtained from the fit (6) to this data. (b) The residuals between the laboratory-determined values of $\delta S_{\mathrm{A}}$ and the values found from the fit (6).

the Panama Canal and if this region was not treated in a special way, the interpolation procedure described above would interpolate the $R^{\delta}$ data of the atlas across this boundary, whereas in fact, it should be a hard boundary across which there should be no such interpolation. The contrast in $R^{\delta}$ values is significant between the two different oceans as can be deduced from the plot of silicate shown in Fig. 7a; at a pressure of $2000 \mathrm{dbar}$ the difference of silicate on either side of the Panama Canal is of the order $150 \mu \mathrm{mol} \mathrm{kg}{ }^{-1}$. Thus Pacific waters should be ignored for interpolations in the Atlantic region and vice versa. An expanded view of the Panama region is shown in Fig. 8 where we also show the simple 5point piecewise linear function of four straight lines in longitude and latitude (in magenta) that separates the two oceans. These five points yield an efficient test to decide if a user's location is in the North Pacific or the North Atlantic. This test is only performed when the location is near this small region of the global ocean.

The other water mass barrier which might potentially need special treatment is the Indonesian archipelago, but in this case there is no problem since (a) water in the Pacific and Indian oceans do communicate above $1200 \mathrm{dbar}$, and (b) at pressures greater than $2000 \mathrm{dbar}$ where the water properties do become significantly different, the two oceans are separated by more than four degrees of latitude and so the issue does not arise.

\section{The Baltic Sea}

Millero and Kremling (1976) were the first to make density measurements using the vibrating tube densimeter technique 

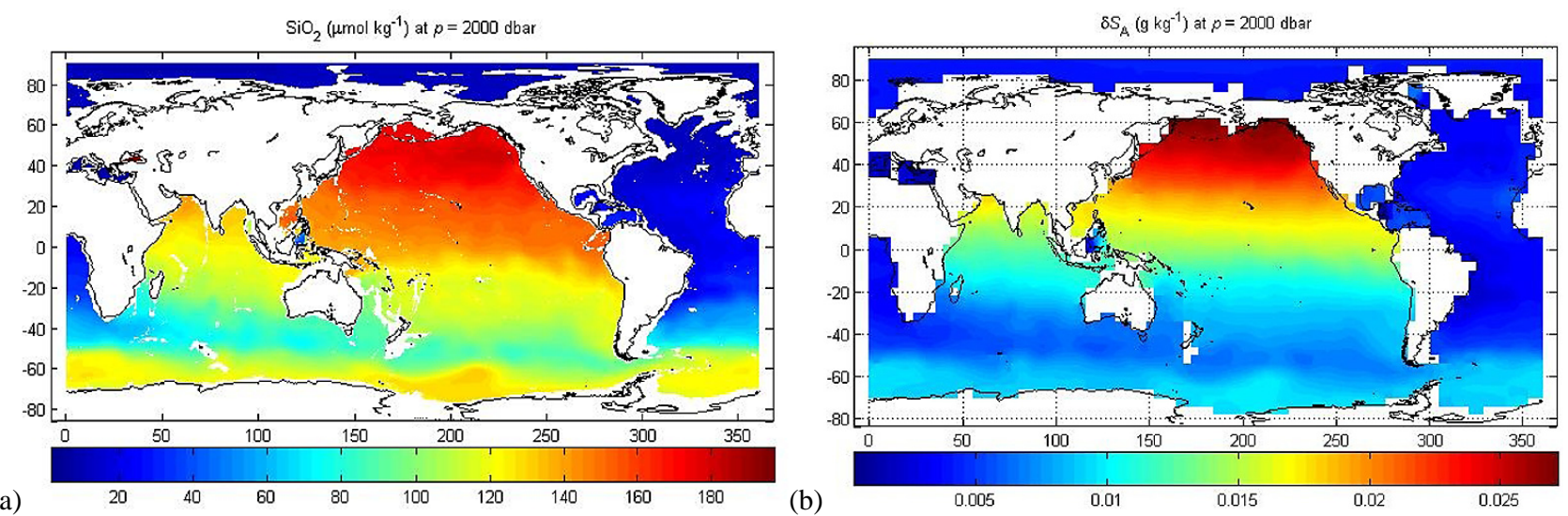

Fig. 7. (a) Silicate data (in $\mu \mathrm{mol} \mathrm{kg} \mathrm{kg}^{-1}$ ) from the Gouretski and Koltermann (2004) atlas plotted at a pressure of $2000 \mathrm{dbar}$ (20 Mpa). (b) The Absolute Salinity Anomaly $\delta S_{\mathrm{A}}$ at the same pressure of $2000 \mathrm{dbar}$.

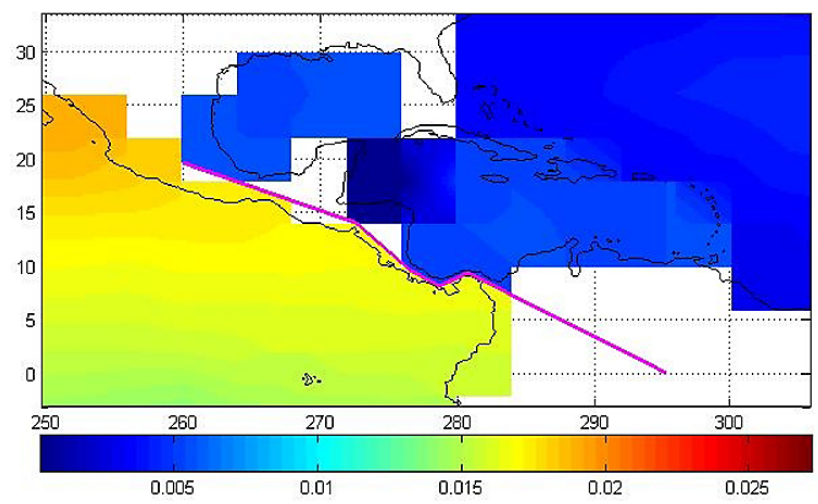

Fig. 8. An expanded view of Fig. $7 b$ showing the series of four straight lines (in magenta) that serve to divide the North Pacific form the North Atlantic in this region.

on samples from the Baltic Sea. More recent measurements have shown that the Absolute Salinity Anomaly $S_{\mathrm{A}}-S_{\mathrm{R}}=$ $\delta S_{\mathrm{A}}$ in the Baltic Sea has been quite variable over the past few decades of observation (Feistel et al., 2010). The present computer algorithm uses the relationship found by Feistel et al. (2010) that applies in the years 2006-2009, namely

$S_{\mathrm{A}}-S_{\mathrm{R}}=\delta S_{\mathrm{A}}=0.087 \mathrm{~g} \mathrm{~kg}^{-1} \times\left(1-S_{\mathrm{R}} / S_{\mathrm{SO}}\right)$ Baltic

where $S_{\mathrm{SO}}=35.16504 \mathrm{~g} \mathrm{~kg}^{-1}$ is the standard-ocean Reference Salinity that corresponds to the Practical Salinity of 35. The Absolute Salinity Anomaly in the Baltic Sea is not due to biogeochemical activity, but rather is due to the rivers bringing material of anomalous composition into the Baltic. Hence Absolute Salinity in the Baltic is a conservative variable. Rewriting Eq. (11) we see that Absolute Salinity in the Baltic Sea is evaluated as

$S_{\mathrm{A}}=\frac{(35.16504-0.087) \mathrm{g} \mathrm{kg}^{-1}}{35} S_{\mathrm{P}}+0.087 \mathrm{~g} \mathrm{~kg}^{-1}$ Baltic Sea

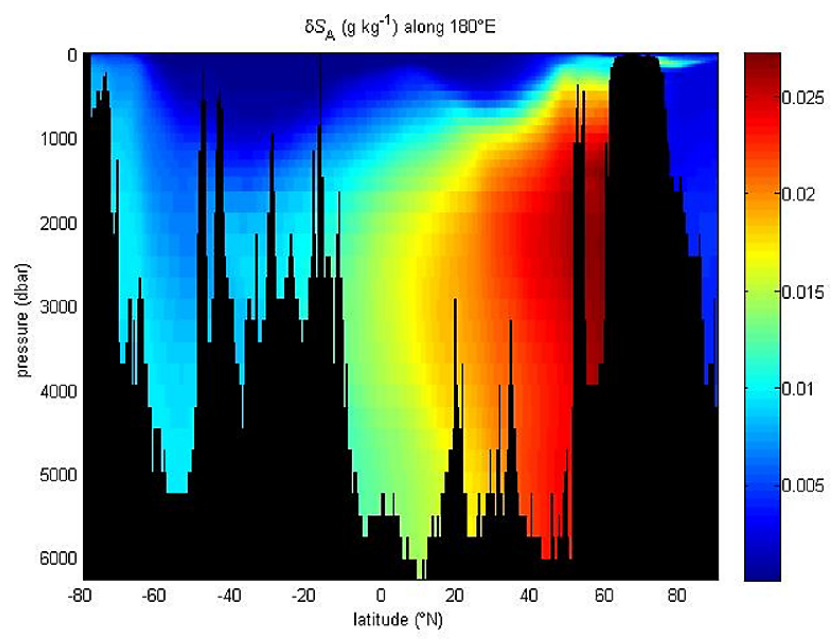

Fig. 9. A vertical section of Absolute Salinity Anomaly $\delta S_{\mathrm{A}}$ along $180^{\circ} \mathrm{E}$ in the Pacific Ocean.

The differences in the formulae for the open ocean and the Baltic Sea arise from the effects of river salts. Since river salts and their effects will vary in different marginal seas, similar, but not identical formulae will eventually be developed for other regions. However, at present the effects of river salts on the physical properties of seawater have not been well studied, and the Baltic Sea is the only marginal sea that is explicitly treated in the TEOS-10 software.

\section{Summary}

The thermodynamic properties of seawater under the TEOS10 international seawater standard are functions of Absolute Salinity $S_{\mathrm{A}}$, and a method is needed to estimate this type of salinity in terms of properties that are routinely measured at sea. Here we have described an algorithm for estimating the Absolute Salinity $\left(\mathrm{g} \mathrm{kg}^{-1}\right)$ of seawater from its 


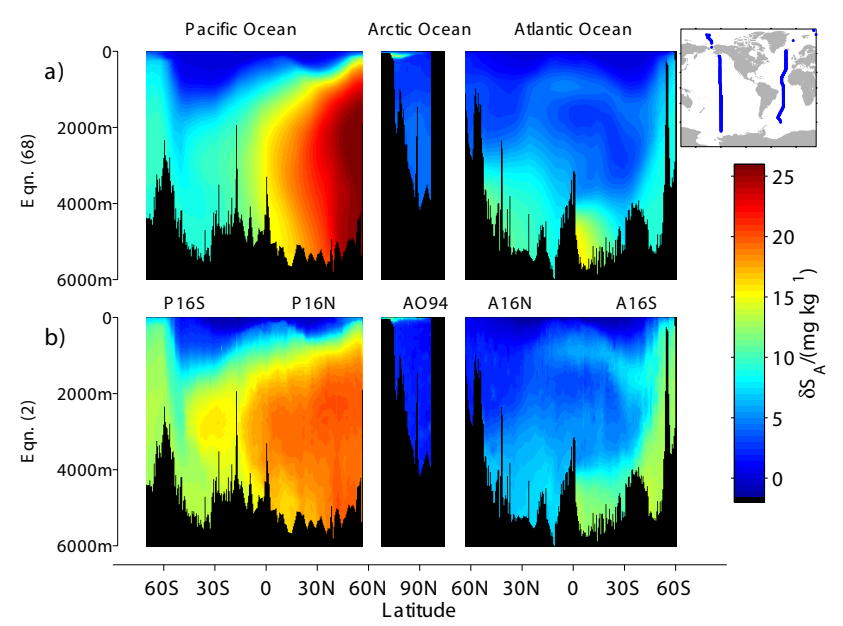

Fig. 10. A comparison between the method of this paper to estimate Absolute Salinity Anomaly with the method of Pawlowicz et al. (2011) (see Eq. (2) above). This figure depicts a "section" running northwards up the Pacific Ocean, through the Arctic Ocean and southwards in the Atlantic Ocean. The upper panels use the method of the present paper, while the lower panels use the extra nutrient and carbon chemistry data and Eq. (2).

Practical Salinity $S_{\mathrm{P}}$ as well as the latitude, longitude and pressure of the seawater sample. The estimated standard error in the resulting value of Absolute Salinity is $0.0048 \mathrm{~g} \mathrm{~kg}^{-1}$ which is considerably less than the standard error involved in present oceanographic practice of effectively equating Absolute Salinity to Reference Salinity $\left(0.0107 \mathrm{~g} \mathrm{~kg}^{-1}\right)$. Some of the remaining error of $0.0048 \mathrm{~g} \mathrm{~kg}^{-1}$ is due to the error in measuring density in the laboratory (perhaps a standard error of $0.0020 \mathrm{~g} \mathrm{~kg}^{-1}$ ) and the remaining error is due to the fact that deviations from the standard relative concentrations of the constituents of seawater are not perfectly correlated with the silicate concentration.

The algorithm exploits the correlation between the difference between Absolute and Reference Salinities and the silicate concentration. The global atlas of silicate values of Gouretski and Koltermann (2004) has been used together with our Eqs. (5)-(8) to enable a simple computer algorithm to deliver estimates of the Absolute Salinity $S_{\mathrm{A}}$ based only on Practical Salinity $S_{\mathrm{P}}$ and knowledge of location. In the Baltic Sea the approach of Feistel et al. (2010) based on the Practical Salinity of the seawater sample has been used (see Eq. (12)). An example of the difference between Absolute Salinity and Reference Salinity, namely the Absolute Salinity Anomaly $\delta S_{\mathrm{A}}=S_{\mathrm{A}}-S_{\mathrm{R}}$, is shown for a meridional vertical section through the Pacific Ocean in Fig. 9.

The algorithm described in the present paper should be regarded as a first attempt at providing a practical means of estimate Absolute Salinity. Many more measurements of density and Practical Salinity on samples collected from around the globe would probably enable the residual error to be reduced in a future algorithm.
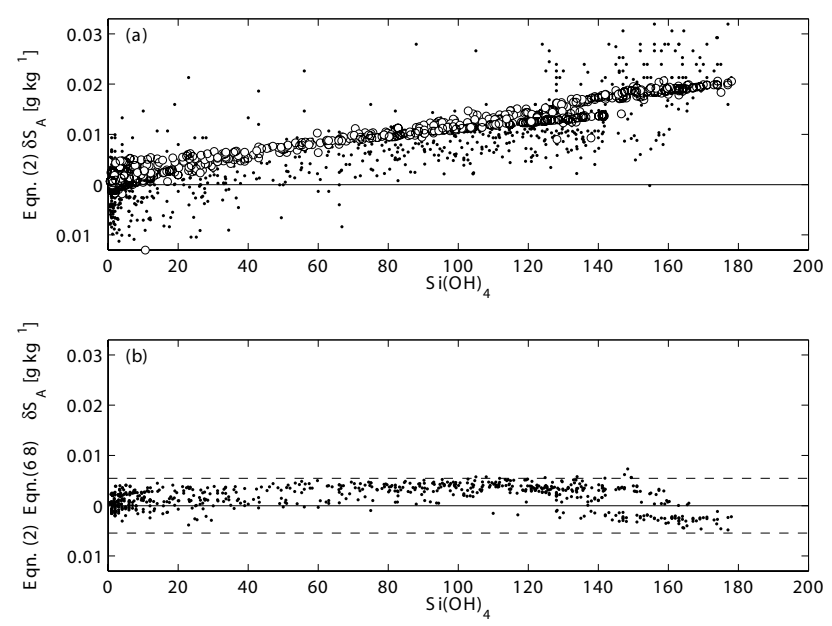

Fig. 11. (a) The dots are the estimates of Absolute Salinity Anomaly $\delta S_{\mathrm{A}}$ based on the laboratory measurements of in situ density and the circles are the estimates of $\delta S_{\mathrm{A}}$ using the nutrient and carbon chemistry data and Eq. (2). (b) The differences between the method of Pawlowicz et al. (2011) (i.e. Eq. (2) above) and the method of the present paper, plotted as a function of silicate concentration. The horizontal dashed lines represent an uncertainty of $\pm 0.004 \mathrm{~kg} \mathrm{~m}^{-3}$ in density, expressed as an uncertainty in $\delta S_{\mathrm{A}}$.

A comparison between the method of the present paper with that of Pawlowicz et al. (2011), which can be used when sufficient nutrient and carbon-chemistry data is available, is shown in Figs. 10 and 11. The differences in $\delta S_{\mathrm{A}}$ between the two methods are less than $0.005 \mathrm{~g} \mathrm{~kg}^{-1}$ (see Fig. 11b), which is less than a fifth of the largest values of $\delta S_{\mathrm{A}}$. It is not known which method is the more accurate, and clearly more research is needed on these aspects of seawater composition.

The computer software, in both FORTRAN and MATLAB, which evaluates Absolute Salinity $S_{\mathrm{A}}$ given the input variables Practical Salinity $S_{\mathrm{P}}$, longitude $\phi$, latitude $\lambda$ and gauge pressure $p$ (in dbar) is available at www.TEOS-10.org. Some introductory articles about TEOS-10 are also available from this web site, namely "Getting started with TEOS10 and the Gibbs Seawater (GSW) Oceanographic Toolbox" (McDougall and Barker, 2011), and "What every oceanographer needs to know about TEOS-10 (The TEOS-10 Primer)" (Pawlowicz, 2010b). The key concepts of TEOS-10 are also described in an introductory set of lecture slides that are publicly available (McDougall, 2012), while Pawlowicz et al. (2012) have written an historical account of the way that TEOS-10 was developed.

Acknowledgements. We thank Steve Rintoul for collecting the seawater samples from the Southern Ocean on the CASO SR3 AA0806 voyage. Andrew Dickson is thanked for helpful comments on a draft of this paper. This work that was partially supported by the US National Science Foundation grant OCE-0608600 to SCOR (Scientific Committee on Oceanic Research), and by IAPSO (International Association for the Physical Sciences of the 
Ocean). FJM wishes to acknowledge the Oceanographic Section of the National Science Foundation and the National Oceanic and Atmospheric Association for supporting his work. This work contributes to the tasks of SCOR/IAPSO Working Group 127.

Edited by: R. Feistel

\section{References}

Brewer, P. G. and Bradshaw, A.: The effect of non-ideal composition of seawater on salinity and density, J. Mar. Res., 33, 157175, 1975.

Feistel, R.: A Gibbs function for seawater thermodynamics for -6 to $80{ }^{\circ} \mathrm{C}$ and salinity up to $120 \mathrm{~g} \mathrm{~kg}^{-1}$, Deep-Sea Res. I, 55, 1639-1671, 2008.

Feistel, R., Wright, D. G., Miyagawa, K., Harvey, A. H., Hruby, J., Jackett, D. R., McDougall, T. J., and Wagner, W.: Mutually consistent thermodynamic potentials for fluid water, ice and seawater: a new standard for oceanography, Ocean Sci., 4, 275-291, doi:10.5194/os-4-275-2008, 2008.

Feistel, R., Weinreben, S., Wolf, H., Seitz, S., Spitzer, P., Adel, B., Nausch, G., Schneider, B., and Wright, D. G.: Density and Absolute Salinity of the Baltic Sea 2006-2009, Ocean Sci., 6, 3-24, doi:10.5194/os-6-3-2010, 2010.

Gouretski, V. V. and Koltermann, K. P.: WOCE global hydrographic climatology. Berichte des Bundesamtes für Seeschifffahrt und Hydrographie Tech. Rep. 35/2004, 49 pp., this atlas is available at: www.bsh.de/aktdat/mk/AIMS, 2004.

IAPWS: Release on the IAPWS Formulation 2008 for the Thermodynamic Properties of Seawater. The International Association for the Properties of Water and Steam, available at: www.iapws. org, Berlin, Germany, September 2008.

IOC, SCOR, and IAPSO: The international thermodynamic equation of seawater - 2010: Calculation and use of thermodynamic properties. Intergovernmental Oceanographic Commission, Manuals and Guides No. 56, UNESCO (English), available at: www.TEOS-10.org, 196 pp., 2010.

Knudsen, M.: Hydrographische Tabellen, G. E. C. Gad, Copenhagen; L. Friedrichsen \& Co., Hamburg; Williams \& Norgate, London; and Buchdruckerei Bianco Luno, 63pp., 1901.

Kremling, K.: New Method for measuring density of seawater, Nature, 229, 109-110, 1971.

McDougall, T. J.: "The International Thermodynamic Equation of Seawater - 2010; Introductory Lecture Slides", available at: www.TEOS-10.org, 2012.

McDougall, T. J. and Barker, P. M.: Getting started with TEOS-10 and the Gibbs Seawater (GSW) Oceanographic Toolbox, www. TEOS-10.org, SCOR/IAPSO WG127, ISBN 978-0-646-556215, 28 pp., 2011.

Millero, F. J.: Effect of changes in the composition of seawater on the density-salinity relationship, Deep-Sea Res. I, 47, 15831590, 2000.
Millero, F. J.: History of the equation of state of seawater, Oceanography, 23, 18-33, 2010.

Millero, F. J. and Kremling, K.: The densities of Baltic Sea waters, Deep-Sea Res., 23, 1129-1138, 1976.

Millero, F. J., Gonzalez, A., Brewer, P. G., Bradshaw, A.: The density of North Atlantic and North Pacific deep waters, Earth Planet. Sci. Lett., 32, 468-472, 1976a.

Millero, F. J., Chetirkin, P. V., and Culkin, F.: The relative conductivity and density of standard seawaters, Deep-Sea Res., 24, 315321, 1976 b.

Millero, F. J., Forsht, D., Means, D., Giekes, J., and Kenyon, K.: The density of North Pacific Ocean waters, J. Geophys. Res., 83, 2359-2364, 1978.

Millero, F. J., Feistel, R., Wright, D. G., and McDougall, T. J.: The composition of Standard Seawater and the definition of the Reference-Composition Salinity Scale, Deep-Sea Res. I, 55, 5072, 2008a.

Millero, F. J., Waters, J., Woosley, R., Huang, F., and Chanson, M.: The effect of composition of the density of Indian Ocean waters, Deep-Sea Res. I, 55, 960-470, 2008b.

Millero, F. J., Mirzaliyev, A., Safarov, J., Huang, F., Chanson, M., Shahverdiyev, A., and Hassel, E.: The equation of state for Caspian Sea waters, Aqua. Geochem., 14, 289-299, 2008c.

Millero, F. J., Huang, F., Williams, N., Waters, J., and R. Woosley: The effect of composition on the density of South Pacific Ocean waters, Mar. Chem., 114, 56-62, 2009.

Pawlowicz, R.: A model for predicting changes in the electrical conductivity, practical salinity, and absolute salinity of seawater due to variations in relative chemical composition, Ocean Sci., 6 , 361-378, doi:10.5194/os-6-361-2010, 2010a.

Pawlowicz, R.: What every oceanographer needs to know about TEOS-10 (The TEOS-10 Primer), unpublished manuscript, available at: www.TEOS-10.org, 2010 b.

Pawlowicz, R., Wright, D. G., and Millero, F. J.: The effects of biogeochemical processes on oceanic conductivity/salinity/density relationships and the characterization of real seawater, Ocean Sci., 7, 363-387, doi:10.5194/os-7-363-2011, 2011.

Pawlowicz, R., McDougall, T., Feistel, R., and Tailleux, R.: An historical perspective on the development of the Thermodynamic Equation of Seawater - Ocean Sci., 8, 161-174, doi:10.5194/os8-161-2012, 2012.

UNESCO: The Practical Salinity Scale 1978 and the International Equation of State of Seawater 1980, UNESCO technical papers in Marine Science, 36, 25 pp., 1981.

UNESCO: Algorithms for computation of fundamental properties of seawater, UNESCO technical papers in Marine Science, 44, 53 pp., 1983.

Wright, D. G., Pawlowicz, R., McDougall, T. J., Feistel, R., and Marion, G. M.: Absolute Salinity, "Density Salinity" and the Reference-Composition Salinity Scale: present and future use in the seawater standard TEOS-10, Ocean Sci., 7, 1-26, doi:10.5194/os-7-1-2011, 2011. 